\title{
Rolling Circle Amplification Is More Sensitive than PCR and Serology-Based Methods in Detection of Banana streak virus in Musa Germplasm
}

\author{
Moses C. Wambulwa ${ }^{1}$, Francis N. Wachira ${ }^{2 *}$, Laura S. Karanja ${ }^{3}$, Samuel M. Muturi ${ }^{1}$ \\ ${ }^{1}$ Department of Biochemistry and Molecular Biology, Egerton University, Njoro, Kenya; ${ }^{2}$ Association for Strengthening Agricultural \\ Research in Eastern and Central Africa (ASARECA), Entebbe, Uganda; ${ }^{3}$ Kenya Agricultural Research Institute, Njoro, Kenya. \\ Email: *f.wachira@asareca.org
}

Received August 15 $5^{\text {th }}, 2012$; revised September 19 $9^{\text {th }}, 2012$; accepted October $5^{\text {th }}, 2012$

\begin{abstract}
Banana (Musa sp.) is a popular and important crop among many communities in East Africa. Banana production is however threatened by the wide-spread banana streak disease (BSD), caused by Banana streak virus (BSV). The success of BSV management is inherently coupled to the availability of a sensitive indexing method. In this study, the sensitivity of three BSV detection techniques: rolling circle amplification (RCA), immunocapture PCR (with degenerate and Gold finger primers) and standard PCR was compared. A set of 32 BSD-asymptomatic samples were used to compare the techniques. Analysis of variance (ANOVA) for comparison of the four techniques showed that there were significant differences $(\mathrm{P}<0.05)$ among all the means, with RCA and direct PCR having the highest detection mean values. Owing to its fidelity and capacity to circumvent the amplification of the integrated nuclear viral sequences, the RCA technique is recommended for routine indexing of Musa tissues for BSV. This study unveils a more reliable BSV detection method, a need that has remained unaddressed for a long while.
\end{abstract}

Keywords: Banana streak virus; Rolling Circle Amplification; Polymerase Chain Reaction

\section{Introduction}

Banana streak disease, caused by Banana streak badnavirus, accounts for up to $90 \%$ yield losses in banana [1]. It also reduces plant growth and vigor, bunch weight and yield [2]. A wide range of cultivars of all genotypes are susceptible including a significant proportion of the improved tetraploid Musa hybrids [3].

A high degree of genomic and serological heterogenity between BSV isolates poses a challenge to reliable indexing of the virus. Moreover, the integration of the virus genome into the host genome $[4,5]$ has been making exclusive nucleic acid-based detection of the virus frustrating, as virtually all Musa tissues test positive to BSV.

The success of banana streak disease control is almost entirely dependent on the availability of accurate, sensitive, low cost and simple diagnostic techniques, which enable early detection of virus infections in plant materials [6]. The commonly used BSV-indexing tools include visual inspection for symptoms which are highly sporadic and may be confused with those of Cucumber mosaic virus (CMV), Immuno-Sorbent Electron Microscopy (ISEM), which is laborious and requires complex and

\footnotetext{
*Corresponding author.
}

expensive equipment, and Enzyme-Linked ImmunoSorbent Assay (ELISA) which has so far proved relatively insensitive [7]. The serological and genomic heterogeneity among BSV isolates has compounded the whole concept of BSV detection [8]. Direct PCR is limited by the integration of viral sequences in the host genome which causes the technique to give false positives in BSV detection. The above enumerated challenges therefore necessitate the search and development of a sensitive tool for BSV diagnostics.

The complexity of molecular detection of BSV is attributed to two factors; first is the presence of integrated sequences in the host genome which might give falsepositives [4] during PCR-based detection procedures. This is the limitation of the standard Polymerase Chain Reaction (PCR) for BSV detection. The high serological variability of the virus is also likely to give false-negatives during serological identification using procedures such as the enzyme linked immuno-sorbent assay (ELISA). To circumvent the challenge posed by the integrated sequences, detection of episomal BSV by PCR may be preceded by an immuno-capture step to prevent amplification of these sequences. This constitutes a technique known as immuno-capture polymerase chain reac- 
tion (IC-PCR). However, IC-PCR is still deficient for $\mathrm{BSV}$ indexing due to the antigenic heterogeneity among the isolates.

This work presents comparative data on three BSV detection techniques. This is the first report on comparison of the novel RCA technique against the other traditional BSV detection techniques.

\section{Materials and Methods}

\subsection{Sample Collection}

Thirty two BSD-asymptomatic banana leaf samples were collected from the Kenya Agricultural Research Institute (K.A.R.I.) Kisii banana field in South Western Kenya. This field had been reported to have a high infection rate of banana streak disease (BSD) about four months before sampling. It was therefore assumed that most of the asymptomatic samples collected were BSV-infected. Details of the collected samples are shown in Table 2. The samples were then packed in silica gel bottles and transported to the Kenya Agricultural Research Institute (K.A.R.I.), Njoro, Kenya. Indexing was done for BSV using RCA, IC-PCR and standard PCR for comparison.

\subsection{Extraction Buffers}

The DNA extraction buffer was prepared by mixing $2 \%$ cetyltrimethylammonium bromide, $100 \mathrm{mM}$ Tris- $\mathrm{HCl}$, $\mathrm{pH}$ 8.0, $50 \mathrm{mM}$ EDTA, $1.4 \mathrm{M} \mathrm{NaCl}, 80 \mathrm{mM} \mathrm{NaSO}_{3}$, and 2\% PVP-10. During buffer mix preparation, all ingredients except CTAB were mixed and made up to $450 \mathrm{ml}$ using deionised water. The $10 \mathrm{~g}$ of CTAB was then dissolved in $50 \mathrm{ml}$ of water in a falcon tube and mixed gently to avoid foaming. The CTAB was then combined with the rest of the buffer solution and mixed well. The BSV extraction buffer on the other hand comprised of 1 litre phosphate buffered saline, $20 \mathrm{~g}$ polyvinylpyrrolidone and $10 \mathrm{~g} \mathrm{Na}_{2} \mathrm{SO}_{3}$.

\subsection{Nucleic Acids Extraction}

Total nucleic acids were isolated from the leaf sample using a modified cetyltrimethylammonium bromide (CTAB) protocol as described by Gawel and Jarret [10] and James et al. [11]. Dry leaf tissue (0.05 g) was ground in liquid nitrogen using pestle and mortar while adding $300 \mu \mathrm{l}$ of the CTAB extraction buffer. The slurry was then incubated at $65^{\circ} \mathrm{C}$ for 15 minutes, spinned at 13,000 rpm and $750 \mu 1$ transferred to a fresh tube. This was then mixed with an equal volume of chloroform/isoamylalcohol (24:1) and centrifuged for 5 minutes at 13,000 rpm. Nucleic acids in the aqueous phase were then pelleted using isopropanol and centrifuged for another 5 minutes at $13,000 \mathrm{rpm}$. The DNA pellet was then washed with
$500 \mu \mathrm{l}$ of $70 \%$ ethanol, and resuspended in $100 \mu \mathrm{l}$ of nuclease-free water. The DNA was left at $4^{\circ} \mathrm{C}$ overnight to fully dissolve. The total nucleic acids extracted were treated with $10 \mathrm{mg} / \mathrm{ml}$ of RNAse A by incubating with 2 $\mu 1$ of RNase A with $100 \mu 1$ of total nucleic acids at $37^{\circ} \mathrm{C}$ for $2 \mathrm{hr}$. The RNase A reaction was terminated by incubating the mixture at $65^{\circ} \mathrm{C}$ for 10 minutes. The nucleic acids were stored at $-20^{\circ} \mathrm{C}$.

The quality of the nucleic acid extracts was tested by both electrophoresis on 1\% agarose gels and PCR for house-keeping genes using a number of randomly selected samples. DNA integrity was ascertained by carrying out actin gene PCR. A PCR master mix of $12.55 \mu \mathrm{l}$ comprised of $1.25 \mu 1$ of PCR buffer, $0.5 \mu 1$ dNTPs, 0.75 $\mu 1$ of $50 \mathrm{mM} \mathrm{MgCl} 2,0.25 \mu 1$ of banana actin forward and reverse primers, $0.05 \mu \mathrm{l} \mathrm{Taq,} 8.75 \mu \mathrm{l} \mathrm{SDW}$ and $1 \mu \mathrm{l}$ of the total nucleic acid extract. The PCR cycling conditions for the actin gene PCR were an initial denaturation at $94^{\circ} \mathrm{C}$ for 2 minutes, 35 cycles $\left(94^{\circ} \mathrm{C}\right.$ for 20 seconds, $57^{\circ} \mathrm{C}$ for 20 seconds and $72^{\circ} \mathrm{C}$ for 30 seconds) and a final extension at $72^{\circ} \mathrm{C}$ for 3 minutes. Electrophoresis for actin gene PCR products was carried out on $1.5 \%$ ethidium bromide-stained agarose gels with Tris-Acetate EDTA (TAE) as running buffer.

The thirty two DNA samples were then separately subjected to three BSV indexing procedures (RCA, standard PCR and IC-PCR). IC-PCR was separately carried out using both degenerate and specific primers. Each treatment was replicated three times. These procedures are outlined in the following sections.

\subsection{Rolling Circle Amplification}

The full Banana streak virus genome was amplified and isolated using the TempliPhi Kit (GE Healthcare) according to James et al. [11]. Two mixes were prepared. In master mix 1 (MM1), $5 \mu$ l of TempliPhi Sample Buffer was mixed with $1 \mu$ of the isolated sample and 1 $\mu 1$ of primer mixture (details shown in Table 1) in an appropriate reaction vessel. This was then heated at $95^{\circ} \mathrm{C}$ for 3 minutes to denature the DNA followed by cooling at $4^{\circ} \mathrm{C}$. Denaturation is necessary because BSV is double stranded. Master Mix 2 (MM2) was prepared by mixing $5 \mu 1$ of TempliPhi Reaction Buffer and $0.2 \mu \mathrm{l}$ of TempliPhi Enzyme Mix. Five microlitres of this TempliPhi premix (mix 2) was transferred to the cooled, denatured sample (MM1) then incubated at $30^{\circ} \mathrm{C}$ for 18 hours. After this incubation period, the enzyme (Phi29 DNA po lymerase) was heat-inactivated at $65^{\circ} \mathrm{C}$ for 10 minutes. The samples were then be cooled and stored at $4^{\circ} \mathrm{C}$.

Ten microlitres of the TempliPhi product from each of the samples were then incubated separately with Stu I (Gibco BRL, Eggenstein) for 2 hours. Stu I was preferred 
Table 1. RCA degenerate primers.

\begin{tabular}{cc}
\hline Primer name & Primer sequence (5'-3') \\
\hline 1 A & CTNTAYGARTGGYTNGTNATGCCNTTYGG \\
BadnaFP & TCCAYTTRCANAYNSCNCCCCANCC \\
BadnaRP & CCAYTTRCAIACISCICCCCAICC \\
BSV2292 & ATGARYTAHATWAGRTGYTMSCC \\
BSV2826 & TYYWGAAARCATGGTGGGRGARGA \\
BSV3298 & YTCCCAYCTTTCRAAKACYTT \\
BSV3517 & KRATMTTYTWTYTDGAARATCC \\
BSV3700 & KTGGBAGTTTKGTRAAGARYTC \\
BSV4030 & TGCARRTGYTWYGCYTGYGGAGA \\
BSV6652 & GAAAARRTMTGYGCNTAYGCVAG \\
\hline
\end{tabular}

over other restriction enzymes due to its capacity to generate distinct polymorphic profiles for the BSV genome. A $20 \mu \mathrm{l}$ aliquot of the digested TempliPhi product was mixed with $2 \mu \mathrm{l}$ of the loading dye (30 $\mathrm{mg} 0.42 \%$ bromophenol blue; $84 \mathrm{mg} 0.42 \%$ xylene xyanol; $12 \mathrm{ml} 60 \%$ glycerol) and electrophoresed for about 20 minutes at $100 \mathrm{~V}$ on a $1 \%$ SYBR Safe-stained agarose gel using $1 \times$ Tris Boric EDTA or Tris Acetate EDTA as the running buffers. The gel was photographed under ultra violet (UV) illumination with Gel Doc (BIO-RAD) Software (USA). Internal standards for BSV isolates generated using Stu I (New England BioLabs) were used to identify the isolate(s) present in each sample.

\subsection{Immuno-Capture Polymerase Chain Reaction}

Immuno-capture Polymerase Chain Reaction (IC-PCR) involved extraction of the leaf sap from all the asymptomatic samples and concentration carried out as described by Harper et al. [12]. One gram of silica gel-dried leaf sample was ground in $5 \mathrm{ml}$ of the BSV extraction buffer. Before carrying out the IC-PCR on all the samples, optimization was done for the antibody and antigen in concentrations of 5:1000, 10:1000 and 15:1000 in the carbonate coating buffer. The optimization was carried out on infected symptomatic tissues. Thin-walled propylene microfuge tubes were coated with polyclonal antibodies. The tubes were then washed three times with $100 \mu$ of PBS-Tween-20. Sap extract (about $100 \mu \mathrm{l}$ ) of the samples was added to each tube then incubated at $37^{\circ} \mathrm{C}$ for 3 hours. The tubes were again washed twice with PBS-T, once with sterile distilled water (SDW) and then dried briefly before carrying out PCR directly in the tubes [12].
The PCR step was carried out using both degenerate and isolate-specific (Gold finger) primers in separate reactions. Two pairs of different types of BSV degenerate primers (badna and Harper's 1A/4') were first evaluated. The badna pair appeared to give more consistent results and was therefore used for this experiment. A 20 $\mu 1$ PCR mix contained $10 \mu \mathrm{l}$ of Go Taq Green master mix (Promega), $0.5 \mu \mathrm{l}$ of each primer at a concentration of 10 $\mathrm{pmol} / \mu \mathrm{l}, 8 \mu \mathrm{l}$ of SDW and $1 \mu \mathrm{l}$ of DNA. The PCR cycle conditions were an initial denaturation at $94^{\circ} \mathrm{C}$ for 5 minutes, 5 cycles $\left(94^{\circ} \mathrm{C}\right.$ for 30 seconds, $37^{\circ} \mathrm{C}$ for 30 seconds and $72^{\circ} \mathrm{C}$ for 1 minute), followed by 30 cycles $\left(94^{\circ} \mathrm{C}\right.$ for 30 seconds, $50^{\circ} \mathrm{C}$ for 30 seconds and $72^{\circ} \mathrm{C}$ for 1 minute) and a final extension at $72^{\circ} \mathrm{C}$ for 10 minutes. The PCR products were electrophoresed on a $1.5 \%$ SYBR Safestained agarose gel as described earlier.

\subsection{Direct PCR}

Direct PCR was carried out on the 32 samples using the Badna degenerate primers only. The PCR mix comprised of $5 \mu 1$ of Top Taq master mix (Qiagen), $0.25 \mu 1$ of each primer at a concentration of $10 \mathrm{pmol} / \mu \mathrm{l}, 3.5 \mu \mathrm{l}$ of SDW and $1 \mu \mathrm{l}$ of DNA. The PCR cycling regimes were an initial denaturation at $94^{\circ} \mathrm{C}$ for 3 minutes, 35 cycles $\left(94^{\circ} \mathrm{C}\right.$ for 30 seconds, $50^{\circ} \mathrm{C}$ for 30 seconds and $72^{\circ} \mathrm{C}$ for 1 minute) and a final extension at $72^{\circ} \mathrm{C}$ for 3 minutes. The PCR products were electrophoresed on a $1.5 \%$ ethidium bromide-stained agarose gel as described earlier.

\section{Results}

Actin gene PCR for DNA samples selected randomly gave expected 664 bp amplicons as shown in Figure 1, confirming that the DNA was intact and of PCR-quality. An evaluation of two degenerate primer pairs to be used for IC-PCR and direct PCR showed that the badna primers were better. Results by the badna primers were reproducible and the bands on agarose gel were more distinct and clearer (Figure 2) than those for 1A/4' [12]. Results of the thirty two asymptomatic (but possibly BSV-infected) samples indexed for BSV using IC-PCR (using both degenerate and Gold finger primers), direct PCR and TempliPhi (RCA) are shown in Figures 3(a)-(c) and Table 2. Direct PCR gave $93.8 \%$ detection with the badna degenerate primers. TempliPhi (RCA) detected the virus in $37.5 \%$ of the samples compared to the $31.3 \%$ with IC-PCR (degenerate primers) and the $14.1 \%$ detections with IC-PCR (Gold finger primers). Analysis of variance (ANOVA) for comparison of the three techniques showed that at $\mathrm{P}<0.05$, there was significant difference among all the means. The ANOVA also showed that at $\mathrm{P}<0.05$, some of the 32 asymptomatic samples differed significantly from one another. 


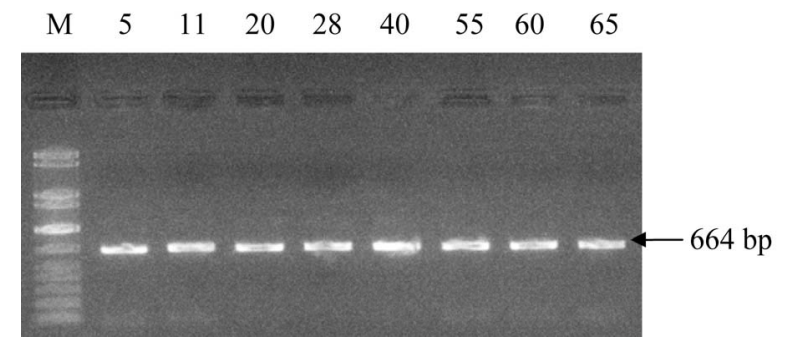

Figure 1. Actin gene PCR for DNA samples selected randomly. Mr is $1 \mathrm{~kb}$ Plus molecular marker.

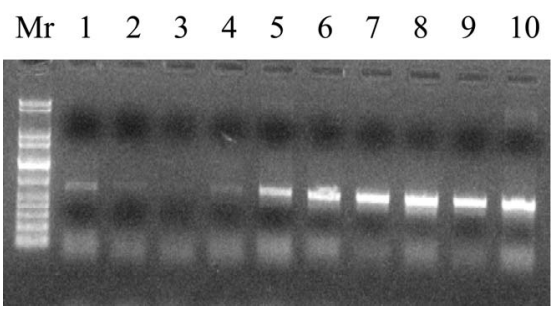

Figure 2. Gel picture showing performance of two BSV degenerate primer pairs. Five BSV-symptomatic samples were used for this evaluation. Lanes 1-5 represent $1 \mathrm{~A} / 4$ ' primers while lanes 6-10 represent badna primers. $\mathrm{Mr}$ is a 1 kb ladder.

This latter observation was expected since direct PCR is known to give false positives for all Musa tissues. Only samples 21 and 27 tested negative with direct/ standard PCR. IC-PCR with goldfinger primers showed 476 bp amplicons on a $1.5 \%$ ethidium bromide-stained agarose gel. These positives were obtained only in samples number 10, 12, 19, 20, 27 and 28.

However, the detections observed in samples 27 and 28 were confirmed as erroneous by a repeat of the same experiment, IC-PCR with degenerate primers and by the rolling circle amplification (RCA) technique. IC-PCR with degenerate primers indicated that the two samples (27 and 28) were negative for BSV. This was also confirmed by RCA.

The analysis presented in Table 3 points out clearly that direct PCR had the highest detection limit (mean = $0.94 \pm 0.00$ ). TempliPhi exhibited a higher mean detection limit than IC-PCR. IC-PCR with Gold finger specific primers gave the lowest mean detection level at 0.14 \pm 0.001 .

\section{Discussion}

The superiority of badna primers over Harper's 1A/4' can be explained on the basis of the high genomic variability inherent within the BSV species. Both badna and $1 \mathrm{~A} / 4^{\prime}$ ' primers are designed to target the replicase (reverse transcriptase/RNase $\mathrm{H}$ ) region of the BSV ORF III. It is possible that natural molecular rearrangements have

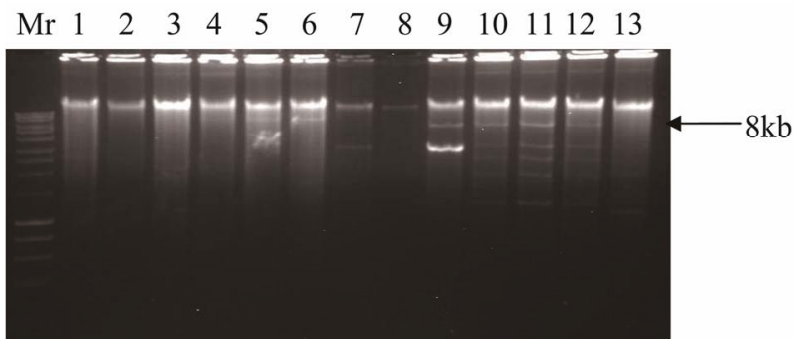

(a)

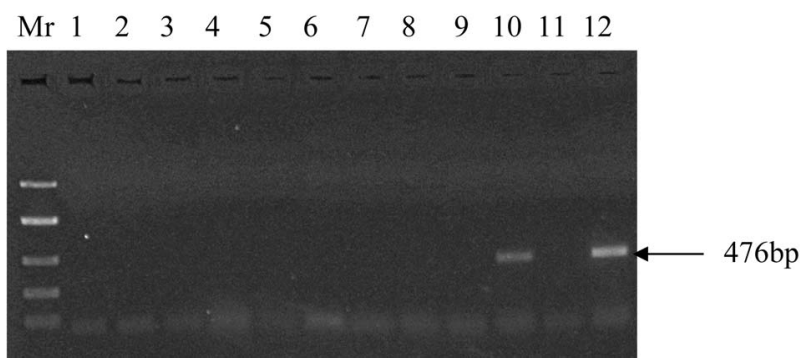

(b)

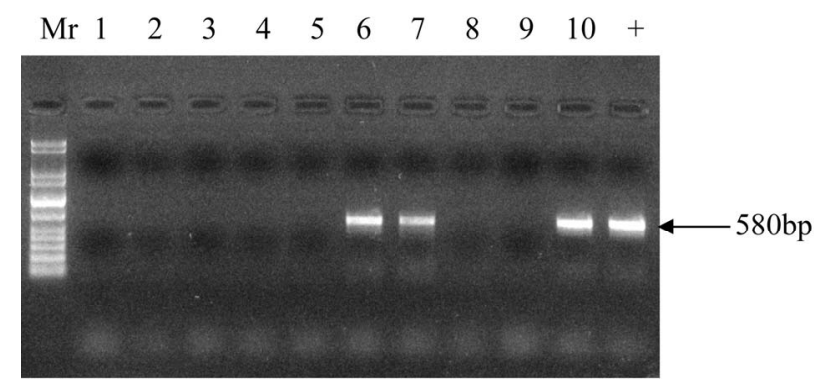

(c)

Figure 3. (a) RCA for samples 1-13. Mr is a $10 \mathrm{~kb}$ ladder; (b) IC-PCR with Gold Finger primers for samples 1-12; (c) IC-PCR with Badna degenerate primers for samples 1-10. + is a positive control (banana leaf sample infected with BSMysV isolate). Mr for $B$ and $C$ is a $1 \mathrm{~kb}$ ladder.

occurred over time within this region of the genome, lowering the capacity of the $1 \mathrm{~A} / 4$ ' primers. This may however be remedied by use of touchdown PCR to determine a suitable annealing temperature. However, in this study, the classical annealing temperature of $50^{\circ} \mathrm{C}$ was used for all BSV PCRs.

IC-PCR technique (both with specific and degenerate primers) amplified BSV sequences from partially purified virus extraction for some of the samples, though with minimal reproducibility. IC-PCR with the gold finger virus specific primers gave a $476 \mathrm{bp}$ fragment while a $580 \mathrm{bp}$ amplicon was observed with the badna degenerate primers. The direct implication

Is that some of the samples had been infected by BSV isolates other than the Gold finger isolate. This confirmed earlier reports of high genomic heterogeneity among BSV isolates [8]. The lower percentage detection 
Methods in Detection of Banana streak virus in Musa Germplasm

Table 2. Details of 32 asymptomatic banana samples assayed for BSV using 3 virus indexing methods with each replicated thrice per sample.

\begin{tabular}{|c|c|c|c|c|c|c|}
\hline Sample number & Cultivar & Genotype & $\begin{array}{c}\text { Direct PCR } \\
\text { (degenerate primers) }\end{array}$ & $\begin{array}{c}\text { IC-PCR } \\
\text { (degenerate primers) }\end{array}$ & $\begin{array}{c}\text { IC-PCR } \\
\text { (Gold finger primers) }\end{array}$ & RCA \\
\hline 1 & Mysore & $\mathrm{AAB}$ & +++ & - & - & - \\
\hline 2 & Mysore & $\mathrm{AAB}$ & +++ & - & - & - \\
\hline 3 & Gold finger & $\mathrm{AAAB}$ & +++ & - & - & - \\
\hline 4 & Mysore & $\mathrm{AAB}$ & +++ & - & - & - \\
\hline 5 & Nshule & EAH-AAA & +++ & -+- & - & +++ \\
\hline 6 & Nshule & EAH-AAA & +++ & +++ & - & +++ \\
\hline 7 & Musera & EAH-AAA & +++ & +++ & - & +++ \\
\hline 8 & Mysore & $\mathrm{AAB}$ & +++ & - & - & - \\
\hline 9 & Gold finger & $\mathrm{AAAB}$ & +++ & - & - & - \\
\hline 10 & Gold finger & AAAB & +++ & +++ & ++- & +++ \\
\hline 11 & Gold finger & $\mathrm{AAAB}$ & +++ & - & - & +++ \\
\hline 12 & Nshule & EAH-AAA & +++ & +++ & -++ & +++ \\
\hline 13 & FHIA 18 & $\mathrm{AAAB}$ & +++ & - & - & - \\
\hline 14 & FHIA 18 & $\mathrm{AAAB}$ & +++ & - & - & - \\
\hline 15 & Solio & EAH-AAA & +++ & +++ & - & +++ \\
\hline 16 & Solio & EAH-AAA & +++ & +++ & - & +++ \\
\hline 17 & Sukari ndizi & $\mathrm{AAB}$ & +++ & - & - & - \\
\hline 18 & Musera & EAH-AAA & +++ & - & - & +++ \\
\hline 19 & Solio & EAH-AAA & +++ & +++ & +++ & +++ \\
\hline 20 & Nusu Ng'ombe & EAH-AAA & +++ & +++ & +++ & - \\
\hline 21 & FHIA 18 & $\mathrm{AAAB}$ & --+ & +++ & - & +++ \\
\hline 22 & Solio & EAH-AAA & +++ & +++ & - & ++- \\
\hline 23 & FHIA 18 & $\mathrm{AAAB}$ & +++ & - & - & - \\
\hline 24 & Solio & EAH-AAA & +++ & - & - & - \\
\hline 25 & Sukari ndizi & $\mathrm{AAB}$ & +++ & - & - & - \\
\hline 26 & FHIA 18 & AAAB & +++ & - & - & - \\
\hline 27 & Cavendish & EAH-AAA & -- & - & -+- & - \\
\hline 28 & FHIA 18 & $\mathrm{AAAB}$ & +++ & - & -++ & - \\
\hline 29 & FHIA 18 & AAAB & +++ & - & - & - \\
\hline 30 & FHIA 18 & AAAB & +++ & - & - & - \\
\hline 31 & FHIA 18 & AAAB & +++ & - & - & - \\
\hline 32 & Solio & EAH-AAA & +++ & --+ & - & - \\
\hline
\end{tabular}

+ Positive detection; - Negative detection. 
Table 3. Comparison based on least significant difference (LSD) test for the four detection techniques.

\begin{tabular}{ccc}
\hline Technique & $\mathbf{N}^{* *}$ & Means $^{*}$ \\
\hline Direct PCR & 96 & $0.94 \pm 0.00$ \\
TempliPhi & 96 & $0.38 \pm 0.019$ \\
IC-PCR (degenerate) & 96 & $0.33 \pm 0.042$ \\
IC-PCR (Gold finger) & 96 & $0.14 \pm 0.001$ \\
\hline
\end{tabular}

$\mathrm{LSD}_{0.05}=0.0354 .{ }^{*}$ Any two means are significantly different if their difference is the greater than LSD value; ${ }^{* *} \mathrm{~N}$ is the total number of replicates.

with Gold finger primers points out to the fact that this primer pair could not amplify thee target sequences of all the BSV isolates. The badna primers are designed to degenerately target the replicase $(\mathrm{RNaseH} / \mathrm{RT})$ region of all members of the Badnavirus genus. Other than Banana streak virus, many other members of the Badnavirus genus are known to exist [13]. Since these viruses are not hosted by banana, it is unlikely that they were amplified by the badna degenerate primers used in this study. To reinforce this further, the antisera used during the immuno-capture step of IC-PCR were specific to BSV.

Although all the 32 samples were asymptomatic, it was possible to detect BSV in some samples. This is because the 32 samples were collected from a field which four months before sampling, was highly endemic with banana streak disease. The implication is that most of the 32 samples were actually infected with BSV but had masked the symptoms probably due to changes in environmental conditions.

Results of this study show that the TempliPhi technique has a greater capacity to reliably detect BSV than the other assayed techniques. This is expected because the TempliPhi technique allows for selective amplification of all circular DNAs within the tissue being indexed [14]. The high sensitivity, fidelity and processivity of Phi29 DNA polymerase, the enzyme involved in TempliPhi amplification [15] ensures accurate and reliable diagnosis by means of this method. A number of factors can be used to explain the lower percentage detection by IC-PCR; the low reproducibility always inherent with IC-PCR, the high serological and genomic heterogeneity known to exist among BSV isolates [8] and probably the inactivity and/or non-specificity of the antisera. Moreover, there appears to be a link between genetic and serological diversity; the former leads to the latter [16]. Since genetic diversity of Banana streak virus has been shown to exist in Kenya [17], it is likely that serological variability among BSV isolates exists with almost the same measure as the genetic diversity.

Apart from the increased sensitivity and reliability of TempliPhi compared to IC-PCR and standard PCR,
TempliPhi has the advantage of allowing the identity of the isolate infecting the sample to be known. This can be an avenue for carrying out more accurate distribution studies for other viruses with circular DNA genomes.

Results for direct PCR and IC-PCR using degenerate primers were not in agreement. Direct PCR gave a $93.75 \%$ detection limit compared to the $31.25 \%$ with ICPCR for the 32 asymptomatic samples. This finding confirms earlier reports of possible integration of badnavirus sequences in their host genomes [4]. Much as most of the detections by direct PCR can therefore be safely classified as false positives, recent studies have tentatively shown that direct PCR for detection of BSV can be reliable for tissues without balbisiana (B) components in their genomes [11]. Banana cultivars of AAA and EAHAAA genomes can be reliably indexed for BSV by means of direct PCR. Direct PCR for sample 27 (AAA cavendish) was indeed a confirmation of this finding. There was no detection of BSV for this sample using all the 3 techniques (direct PCR, IC-PCR and TempliPhi). More so, the positive detections observed with direct PCR for tissues with AAA genomes were confirmed by the other techniques. Therefore direct PCR in this case can be relied upon. However, the negative result observed for sample 21 was certainly erroneous since it was not in agreement with the results of the other techniques. The likely explanation is that the DNA for this sample was not of PCR quality.

As yet, it is not clear why the integrated sequences are never amplified by direct PCR in tissues exclusively containing acuminata (A) genome but earlier studies have established that the numerous infectious BSV endogenous pararetroviruses (integrated sequences) of different BSV species are restricted to the B genome [18]. According to these studies, the integrated sequences in $\mathrm{A}$ genomes are usually non-infectious; they cannot be activated by the tissue culture stress. This suggests that the non-detectability of these endogenous pararetroviruses in A genomes is linked to the position of these sequences in the genome.

It is an undisputed fact that rapid and reliable detection of Banana streak virus has been an enormous challenge over the last two decades. Although the RCA technique offers a remedy to this problem, the solution seems to be only partial. The long incubation period, need for incubation and electrophoresis apparatus required for the RCA method have meant that this technique cannot be used in the field for rapid indexing of banana samples, a need which has remained unaddressed for a long time. It would be worthwhile for future research to focus on establishing a method based on the rolling circle amplification principle that will circumvent the long incubation periods and the electrophoretic procedures. 


\section{Acknowledgements}

We would like to thank the Queensland University of Technology (QUT), Australia, through the Banana 21 project for funding this work. Special thanks also go to the Kenya Agricultural Research Institute, Njoro for availing laboratory facilities.

\section{REFERENCES}

[1] J. W. Daniells, A. D. W. Geering, N. J. Brynde and J. E. Thomas, "The Effect of Banana streak virus on the Growth and Yield of Dessert Bananas in Tropical Australia," Annals of Applied Biology, Vol. 139, No. 1, 2001, pp. 51-60. doi:10.1111/j.1744-7348.2001.tb00130.x

[2] B. E. L. Lockhart and D. R. Jones, "Banana Streak," In: D. R. Jones, Ed., Diseases of Banana, Abacá and Ensete, CABI Publishing, Oxon, 1999, pp. 262-274.

[3] B. E. L. Lockhart, T. C. Ndowora, N. E. Olszewski and G. Dahal, "Studies on Integration of Banana streak badnavirus Sequences in Musa: Identification of EpisomallyExpressible Badnaviral Integrants in Musa Genotypes," In: E. A. Frison and S. E. Sharrock, Eds., Banana streak virus: A Unique Virus-Musa Interaction: Proceedings of a Workshop of the PROMUSA Virology Working Group, Montpellier, 19-21 January 1998, pp. 35-42.

[4] A. D. W. Geering, J. N. Parry, L. Zhang, N. Olszewski, B. E. L. Lockhart and J. E. Thomas, "Is Banana streak virus Strain OL the Only Activatable Virus Integrant in the Musa Genome?" Proceedings of the 2nd International Conference on Molecular Cellular Biology of Banana, InfoMusa, Vol. 10, No. 2, 2001, pp. 13-20.

[5] G. Harper, R. Hull, B. E. L. Lockhart and N. Olszewski, "Viral Sequences Integrated into Plant Genomes," Annual Review of Phytopathology, Vol. 40, 2002, pp. 119-136. doi:10.1146/annurev.phyto.40.120301.105642

[6] International Network for the Improvement of Banana and Plantain (INIBAP), "Report of the Meeting," In: E. A. Frison and S. E. Sharrock, Eds., Banana streak virus: A Unique Virus-Musa Interaction: Proceedings of a Workshop of the PROMUSA Virology Working Group, Montpellier, 19-21 January 1997, pp. 7-14.

[7] G. Thottappilly, G. Dahal and B. E. L. Lockhart, "Studies on a Nigerian Isolate of Banana streak badnavirus. I. Purification and Enzyme-Linked Immunoassay," Annals of Applied Biology, Vol. 132, No. 2, 1998, pp. 253-261. doi:10.1111/j.1744-7348.1998.tb05201.x

[8] B. E. L. Lockhart and N. E. Olszewski, "Serological and Genomic Heterogeneity of Banana streak badnavirus: Implications for Virus Detection in Musa Germplasm," In: J. Ganry, Ed., Breeding Banana and Plantain for Resistance to Diseases and Pests, CIRAD, Montpellier, 1993, pp. 105-130.
[9] D. Haible, S. Kober and H. Jeske, "Rolling Circle Amplification Revolutionizes Diagnosis and Genomics of Geminiviruses," Journal of Virological Methods, Vol. 135, No. 1, 2006, pp. 9-16. doi:10.1016/i.jviromet.2006.01.017

[10] N. J. Gawel and R. L. Jarret, "A Modified CTAB Extraction Procedure for Musa and Ipomoea," Plant Molecular Biology Reporter, Vol. 9, No. 3, 1991, pp. 262-266. doi:10.1007/BF02672076

[11] A, P. James, R. J. Geijskes, J. L. Dale and R. M. Harding, "Development of a Novel Rolling-Circle Amplification Technique to Detect Banana streak virus Which Also Discriminates between Integrated and Episomal Virus Sequences," Plant Disease, Vol. 95, No. 1, 2011, pp. 57 62.

[12] G. Harper, D. Hart, S. Moult and R. Hull, "Detection of Banana streak virus in Field Samples of Bananas from Uganda," Annals of Applied Biology, Vol. 141, No. 3, 2002b, pp. 247-257. doi:10.1111/j.1744-7348.2002.tb00216.x

[13] M. Bousalem, E. J. P. Douzery and S. E. Seal, "Taxonomy, Molecular Phylogeny and Evolution of Plant Reverse Transcribing Viruses (Family Caulimoviridae) Inferred from Full-Length Genome and Reverse Transcriptase Sequences," Archives of Virology, Vol. 153, No. 6, 2008, pp. 1085-1102. doi:10.1007/s00705-008-0095-9

[14] L. Blanco and M. Salas, "Relating Structure to Function in Phi29 DNA Polymerase," Journal of Biological Chemistry, Vol. 271, No. 15, 1996, pp. 8509-8512. doi:10.1074/jbc.271.15.8509

[15] L. Blanco, A. Bernad, J. M. Lazaro, G. Martin, C. Garmendia and M. Salas, "Highly Efficient DNA Synthesis by the Phage Phi29 DNA Polymerase," Journal of Biological Chemistry, Vol. 264, No. 15, 1989, pp. $8935-$ 8940.

[16] B. O. Agindotan, G. Thottappilly, A. Uwaifo and S. Winter, "Production of Monoclonal and Polyclonal Antibodies against a Nigerian Isolate of Banana streak virus," African Journal of Biotechnology, Vol. 2, No. 7, 2003, pp. 171-178.

[17] L. Karanja, A. Wangai, G. Harper and R. S. Pathak, "Molecular Identification of Banana streak virus Isolates in Kenya," Journal of Phytopathology, Vol. 156, No. 11-12, 2008, pp. 678-686. doi:10.1111/j.1439-0434.2008.01415.x

[18] G. Dahal, F. Dahal, C. Pasberg-Gauhl, J. D. A. Hughes, G. Thottapilly and B. E. L. Lockhart, "Evaluation of Micropropagated Plantain and Banana (Musa spp.) for Banana streak badnavirus Incidence Under Field and Screenhouse Conditions in Nigeria," Annals Applied Biology, Vol. 134, No. 2, 1999, pp. 181-191 doi:10.1111/j.1744-7348.1999.tb05254.x 